\title{
Methodology for the Development of a Human Resource Management System Under the Conditions of a Highly Competitive Innovative and Digital Economy
}

\author{
Nikolaev N.A.
}

\author{
Ural State University of Economics, Ekaterinburg, Russia \\ *Corresponding author. Email: Wagner83@mail.ru
}

\begin{abstract}
The article provides methodology of the personnel management system that is developed and justified on the scientific basis. The relevance of the research is determined by the company's need to gain the desired dynamics in an intensively competitive innovative digital economy and the lack of scientific reasearch conducted on methodological principles of efficient personnel management system.

The methodological basis of the research includes the methodological principles of human relations theory, human resources management, organizational management theories, and theories of human capital.

Methodological approach is developed using the methods of system, structural and functional analysis. The approach is aimed at to evaluating the properties of personnel management system based on the author's criteria, metods, indicators.

Methodology of personnel management system is developed with a wide range of analyses: system analysis, logical analysis, comparative aanlysis, situational approach, structure and function-based analysis; the reseach findings implemented in the companies loacted in the Sverdlovsk Region are represented.
\end{abstract}

Keywords: personnel management system in the innovative environment and digital economy, $H R$

management system, methodology of HR management system

\section{INTRODUCTION}

Russia's development strategy 2030 represents a new model of economic growth which is directed at increasing the labour efficiency with the decrease in economically active population and with the appearance of a new innovative and digital economy.

Increasing labour productivity is extremely significant in implementing improvement plans. Increased labour efficiency and safety is an integral part of staying competitive in an intensively competitive innovative environment through continuous improvement of innovative activity.

Despite the ongoing technical advances in companies, labor productivity in Russian industrial enterprises remains 3-4 times lower than that in the USA enterprises.

According to the data provided by the Organization for economic co-operation and development (OECD), the productivity of 1 person-hour of work in Russia is 25.9 US dollars, that in the countries of the European Union is 55,9 USA dollars, in the United States of America - 72 US dollars. This indicates significant reserves for increasing the labor efficiency of domestic enterprises.

It is necessary to supervise personnel management system within a framework of the development strategy in order to increase the company performance and labour productivity. Owners and management determine the goals and strategy of the enterprise, while the staff implements plans to achieve the goals. Staff formation and performance are determined by the personnel management system. On the one hand, the personnel management system implements the company's development strategy, and on the other hand, the company's development strategy should be determined taking into account the state of the personnel management system and the labor potential.

The scientific study of literature revealed a wide range of publications on the company's HR management systems.

However, the analysis of scientific and methodological literature revealed insufficient research of methodology related to personnel management system in an intensively competitive innovative environment which is characterized by high dynamics, innovations that provide competitive advantages, increasing competition. To do this, HR management system is to design new properties that will make the personnel competitive, effective and efficient and create sustainable competitive advantages and the desired dynamics of company's performance.

The relevance and purpose of the research is determined by the need to develop a methodology of the personnel management system in an intensively competitive innovative environment to ensure a sustainable increase in the competitiveness of Russian companies. 
The works written by R. A. Dolzhenko are devoted to the issues of implementing innovations in the personnel management system [10].

The works written by Myasova O. S. [11], Zaitseva N. A. [12], Nagimova Z. A. [13], etc. are focused on the specific features of personnel management in various economic sectors.

It should be noted that the majority of approaches to developing a methodology of HR management system is considered situational, i.e. managerial structure and methods are determined by the goals and objectives of improving the system.

As can be seen from the analysis of scientific literature methods of developing and improving of HR management systems are described by many authors. However, in the course of studying scientific publications, we found no publications on the methodology of developing HR management system aimed to provide key properties in a highly competitive and innovative environment: purposeful activities, staff motivation to achieve the goals, desired type of labor relations, quantity and quality of human resources, effective implementation of personnel management functions.

This article is devoted to the methodology of developing HR management system in an intensively competitive innovative environment based on cyclical changes in the subsystems.

\section{METHODOLOGY}

The key function of the personnel management system regarded as a key subsystem of the company is to provide the desired quantity and quality of human resources and to organize an effective reproduction and development in a highly competitive innovative environment. From this standpoint, the key properties of the personnel management system are purposeful activities, staff motivation to achieve the goals of the company, staff coordination, adequate relation between the quantity and quality of human resources and company's goals, quality audit. These properties should be used as criteria for evaluating the personnel management system in a highly competitive innovative environment. The properties of personnel management system that contain the criteria proposed by the author are presented in Table 1 .

Table 1 Criteria for evaluating the properties of the personnel management system

\begin{tabular}{|c|c|}
\hline Criteria & Properties \\
\hline 1. Purposeful activities & characterizes the direction and purposeful activities. It shows the degree of purposefulness indicated in performing duties. \\
\hline $\begin{array}{l}\text { 2. Staff motivation to perform duties and } \\
\text { achieve company's goals }\end{array}$ & $\begin{array}{l}\text { It characterizes internal staff motivation perform t duties and achieve the goals. It shows the level of motivation to achieve } \\
\text { the company's goals. }\end{array}$ \\
\hline $\begin{array}{l}\text { 3. Type of social and labour relations in the } \\
\text { process of achieving goals }\end{array}$ & $\begin{array}{l}\text { It characterizes the socio-economic and psychological aspects of interaction between employees in team work: ethical, } \\
\text { aesthetic and moral values, personal involvement, coordination, specific features of socio-psychological climate, personal } \\
\text { relationship between employees. }\end{array}$ \\
\hline $\begin{array}{l}\text { 4. Correlation between quality and quantity } \\
\text { of human resources and labour requirements }\end{array}$ & $\begin{array}{l}\text { It characterizes the correlation between quantity and quality of human resources, meeting lab our requirements, and the } \\
\text { company's dynamics in an intensely competitive innovative environment. It includes the qualifications, health, creativity, } \\
\text { etc. }\end{array}$ \\
\hline 5. Implementing HR functions & $\begin{array}{l}\text { It characterizes implementing HR functions in terms of achieving the company's goals and gaining the desired dynamics: } \\
\text { selection, recruitment, planning, labor control, etc. }\end{array}$ \\
\hline
\end{tabular}


Therefore, HR management system shouldn't be regarded as one of the subsystems along with finance management system, for example, but as an equipollent system that determines long-term or short-term company's competitiveness.

To perform it, the methodology of developing HR management system has to be amended in an intensely competitive innovative environment. The aspects that need to be amended are as follows: goals, criteria, indicators, results, performance, management methods, system correlation method, sequencing (see Table 2). term competitiveness through developing a system of strategic management, manufacturing, technology without building HR management system are considered failed.

Traditionally, HR management strategy is determined by company's development strategy. HR manageme management system: formation, utilization and development. HR management is a crucial factor for improving company's competitiveness in an intensely competitive innovative environment and a new knowledge economy. Under these circumstances the attempts to provide long-

Table 2 Specific features of traditional and proposed (complimentary) approach to managing the development of HR management system.

\begin{tabular}{|c|c|}
\hline Traditional approach & Proposed (complementary) approach \\
\hline \multicolumn{2}{|c|}{ System correlation model } \\
\hline $\begin{array}{l}\text { HR management system performs a service function in } \\
\text { organizational management system }\end{array}$ & $\begin{array}{l}\text { HR management system is an equivalent system with organizational } \\
\text { management system which determines the competitiveness and } \\
\text { dynamics in an intensely competitive innovative environment. }\end{array}$ \\
\hline \multicolumn{2}{|c|}{ Goal of HR management system } \\
\hline Providing the organization with highly trained human resources & $\begin{array}{l}\text { Formation, utilization and development of human resources aimed to } \\
\text { gain efficiency and dynamics in a rapidly changing environment. }\end{array}$ \\
\hline \multicolumn{2}{|c|}{ Criteria for evaluating the development and improvements processes of HR management system } \\
\hline $\begin{array}{l}\text { Economic efficiency, social effectiveness of projects aimed to } \\
\text { improve HR management system, risks. }\end{array}$ & $\begin{array}{c}\text { Economic efficiency, social effectiveness of projects aimed to improve } \\
\text { HR management system, risks. } \\
\text { Personnel competitiveness, determination, the level of staff motivation } \\
\text { to achieve the goals, type of social and labor relations, correlation } \\
\text { between quantity and quality of human resources and the objectives, } \\
\text { implementing HR functions. }\end{array}$ \\
\hline \multicolumn{2}{|c|}{ Indicators of developing and improving HR management system } \\
\hline $\begin{array}{c}\text { Net present value (NPV), return on investment (ROI), job } \\
\text { satisfaction, staff turnover, number of social and labor conflicts, } \\
\text { proportion of employees performing jobs in unfavorable or harmful } \\
\text { working conditions, etc. }\end{array}$ & $\begin{array}{l}\text { Net present value (NPV), return on investment (ROI), job satisfaction, } \\
\text { staff turnover, number of social and labor conflicts, proportion of } \\
\text { employees performing jobs in unfavorable or harmful working } \\
\text { conditions, etc. } \\
\text { Indicators: purposeful activities, staff motivation; coefficient of social } \\
\text { and labour relations; the ratio of job requirements and company's } \\
\text { goals; coefficient of implementing HR management functions and } \\
\text { company's dynamics }\end{array}$ \\
\hline \multicolumn{2}{|r|}{ Results } \\
\hline $\begin{array}{l}\text { Improving socio-economic indicators of HR management system: } \\
\text { net present value, return on investment index, employee satisfaction, } \\
\text { reduced staff turnover, etc. }\end{array}$ & $\begin{array}{l}\text { Increasing socio-economic indicators of HR management system: net } \\
\text { present value, profitability index, return on investment, employee } \\
\text { satisfaction, reduced turnover and personal involvement, dynamics, HR } \\
\text { competitiveness. }\end{array}$ \\
\hline \multicolumn{2}{|c|}{ Model of developing HR management system } \\
\hline $\begin{array}{l}\text { Company's development strategy determines HR management } \\
\text { system, functional subsystems, functions, methods and tools of HR } \\
\text { management. } \\
\text { First it is planned to develop the company and then the appropriate } \\
\text { changes in HR management system. } \\
\text { Company's development strategies } \rightarrow \text { HR management system }\end{array}$ & $\begin{array}{l}\text { The company's development strategy is determined and amended in } \\
\text { relation to HR management system, functional subsystems, methods } \\
\text { and HR tools. } \\
\text { Business is planned, amended and implemented in a balanced way in } \\
\text { relation to the developing HR management system. } \\
\text { Company's development strategy } \leftrightarrow \text { HR management system }\end{array}$ \\
\hline
\end{tabular}

The requirements of HR management system are systemized on the basis of concept cyclic system development that takes into account specific features of developing personnel management system: purposeful activities, level of labour motivation, social and labour relations, meeting labour requirements, implementation of HR management functions. Each feature is defined in relation to all elements of development: goal setting and evaluation of the system, system development planning, increasing staff motivation, developing a system of HR management system, output monitoring.

In the course of developing the methodology, the methods tested in Russian small and large enterprises working in various sectors of the economy were analyzed. Methods were tested to reveal the efficiency to manage the development process that takes into account the specific features. This approach identified the most effective methods to manage the development of HR management 
system. When choosing methods for managing the development of HR management system, special attention was paid to the aspects of gaining the desired company's dynamics in an intensely competitive innovative environment (see Appendix 1).

The essential feature of the methodology lies in defining and implementing a set of management methods and arrangements aimed at transforming the personnel management system, improving staff motivation, improvement plans and company's competitiveness in an intensely competitive innovative environment.

The development of personnel management system is managed with a cycle that includes development planning, changes in personnel management system; the assessment of the system, coordination, organization, follow-up monitoring within a framework of the structure, functions, methods and tools of personnel management, institutionalizing changes in the management documents. The scheme of managing the development process of HR management system in relation to the implementing the development strategy is shown in Figure 1.

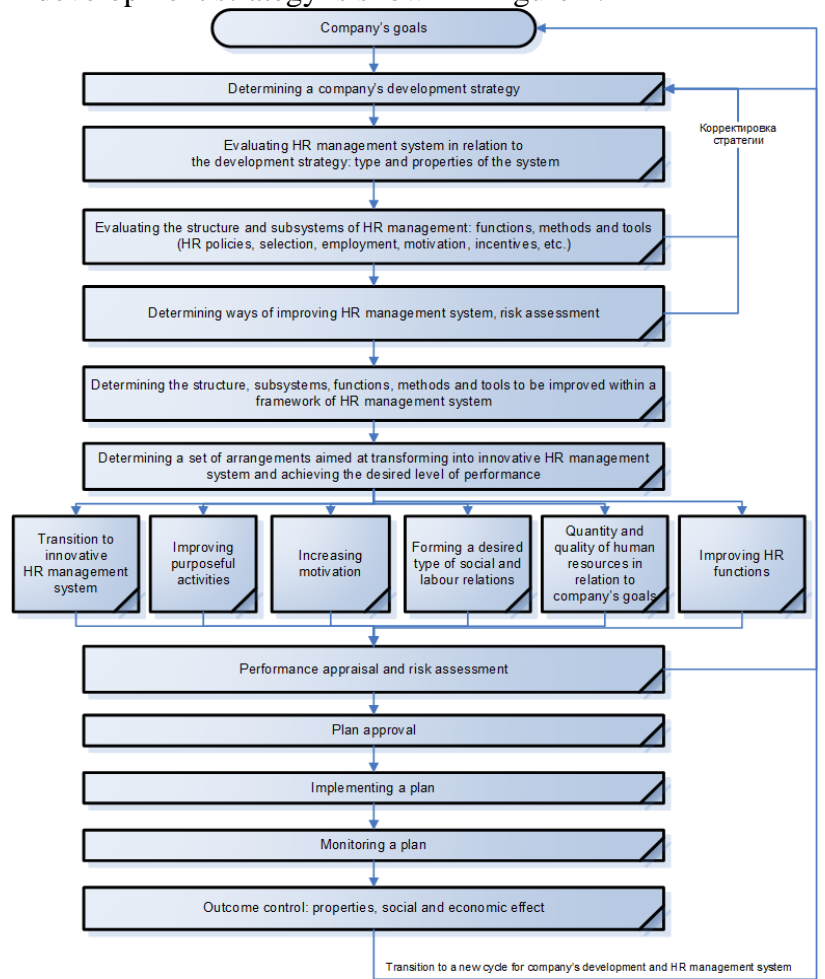

Figure 1 Scheme of managing the development process of HR management system

The scheme of managing the development process of $\mathrm{HR}$ management system differs from the existing ones in the scientific and methodological literature:

- sequence of steps from setting a goal to implementing an improvement plan that ensures necessary and sufficient properties of the system to achieve the goal;
- the correlation between the development strategies and the changes in the personnel management system. The owners and management of the company set a purpose, direction, strategy and development rates. The coordinated activities of highly motivated personnel provide high performance to achieve tangible results in implementing strategies and building HR management system .

\section{FINDINGS AND CONCLUSIONS}

The methodology of managing the development of HR management system in an intensely competitive innovative environment applied small and large enterprises located in the Sverdlovsk and Chelyabinsk improved the main properties of enterprise's HR management systems and increased performance indicators over the period 20132019. Thus, the methodology applied in a production and trade enterprise located in the Sverdlovsk region gave the following results:

- labour productivity and implementing development plans of RT enterprise increased by 1.8 times;

- indicator of purposeful activities increased by 1.33 times;

- average level of staff motivation to achieve the company's goals and perform duties increased by 1.25 times;

- average coefficient of social and labor relations increased by 1.37 times;

- coefficient of meeting labour requirements and achieving the company's goals increased by 1.49 times;

- quality coefficient of implementing HR management functions increased by 1.4 times;

- relative company's dynamics in relation with competitors in terms of bringing new and improved products to the market increased by 1.35 times.

The change in the enterprise's HR management system and in the developed competitive strategy increased the revenue by 2.85 times and net profit by 2.65 times over the period from 2013 to 2019. The company's market share in relation to its competitors increased from $2.5 \%$ to $8 \%$. The overall economic effect of improving the company's HR management system and implementing a developed competitive strategy was 18 million roubles.

Implementing a methodology of managing the development of HR management system contributes to competitiveness of Russian companies in all sectors of economy, increases dynamics by at least $10-30 \%$ and economic efficiency by $10 \%$; improves social indicators: job satisfaction, reduced turnover, etc. 
[7] E.A. Grudneva, D.Yu. Fraimovich, Analysis of methods for researching the effectiveness of the personnel management system, Bulletin of Vladimir State University named after Alexander Grigoryevich and Nikolai Grigoryevich Stoletov. Series: Economic Sciences, 2 (20) (2019) 60-68

[2] B.N. Gerasimov, Development of the organization's personnel management process, International Journal of Humanities and Natural Sciences, 2017

[3] V.A. Karavaev, Ways to improve the personnel management system of the company, Siberian Financial School, 2 (91) (2012) 105-107

[4] A.A. Dorofeeva, N.V. Furaeva, Justification of the feasibility of improving the personnel management motivation system in the marketing activities of a trading enterprise, Industrial Economics, 4 (56) (2011) 344-351

[5] A.Yu. Mistletoe, Improving the personnel management system through the development of the motivational process in a scientific organization, the North and the market: the formation of an economic order, 2 (30) (2012) 116a-124

[6] C. N. Bayukova, Study of personnel management systems, basic approaches and methods, Models, systems, networks in economics, technology, nature and society, 1 (13) (2015) 21-26

[8] N.M. Deaf, Classification of methods for the study of personnel management systems by the example of theses, Scientific Opinion, 8 (2013) 216-219

[9] N.M. Glukhenkaya, Perfection of the study of personnel management systems: a diversification approach, Modern problems of science and education, 5 (2015) 445

[10] R.A. Dolzhenko, Innovations in the organization's personnel management system, Bulletin of Altai State Agrarian University, 1 (99) (2013) 149-153

[11] O.S. Mysova, Specifics of personnel management as a subsystem of hotel management, Bulletin of the Kemerovo State University, 1-4 (61) (2015) 230-234

[12] N.A. Zaitseva, Personnel management in hotels: a training manual, M.: FORUM: INFA-M, 2013

[13] Z.A. Nagimova, Human Resource Management in the Hotel Business, St. Petersburg, 2009 
Appendix 1 - Methods of supervising the development process of HR management system aimed at acquiring desired properties

\begin{tabular}{|c|c|c|c|c|c|}
\hline \multirow{2}{*}{$\begin{array}{l}\text { Stages of cycle of } \\
\text { supervising the } \\
\text { development process } \\
\text { of HR management } \\
\text { system }\end{array}$} & \multicolumn{5}{|c|}{ Properties of HR management system } \\
\hline & Purposeful activities & \begin{tabular}{|c|}
$\begin{array}{c}\text { Staff motivation to perform duties and } \\
\text { achieve company's goals }\end{array}$ \\
\end{tabular} & $\begin{array}{l}\text { Type of social and labour relations in } \\
\text { the process of achieving goals }\end{array}$ & $\begin{array}{c}\text { Correlation between quality and } \\
\text { quantity of human resources and } \\
\text { labour requirements }\end{array}$ & Implementing HR functions \\
\hline $\begin{array}{l}\text { 1. Goal-setting, } \\
\text { evaluation, socio- } \\
\text { economic analysis of } \\
\text { prospects. Evaluating } \\
\text { HR management } \\
\text { system, functional } \\
\text { subsystems, elements, } \\
\text { functions. }\end{array}$ & $\begin{array}{l}\text { Analysis of the company's strategic } \\
\text { position. } \\
\text { Setting goals for the company's } \\
\text { competitive strategy. } \\
\text { Decomposing company's goals into goals, } \\
\text { functions of subsystems, and HR } \\
\text { management elements. } \\
\text { Function and cost-based analysis of HR } \\
\text { management system and the prospects. } \\
\text { Monitoring labor behavior, calculation } \\
\text { and analysis of indicators of purposeful } \\
\text { activities. } \\
\text { Modelling HR management system in } \\
\text { relation to the company's development } \\
\text { strategy. }\end{array}$ & $\begin{array}{l}\text { Calculation of real and desired motivation } \\
\text { indicators, comparative analysis of } \\
\text { employee motivation indicators. } \\
\text { Observation of labour behavior, } \\
\text { interviewing managers and executives. } \\
\text { Employee survey on the impact of the } \\
\text { incentive system and working conditions } \\
\text { on motivation to perform duties and } \\
\text { personal involvement. } \\
\text { Simulation of changes in the incentive } \\
\text { system and working conditions on the } \\
\text { level of staff motivation, correlation } \\
\text { between changes in the incentive system } \\
\text { and performance responsibility. }\end{array}$ & $\begin{array}{l}\text { Monitoring of labor } \text { behavior, } \\
\text { psychological climate, personal } \\
\text { relationship, coordination of interaction } \\
\text { and personal involvement. } \\
\text { Analysis of management and legal } \\
\text { documents regulating social and labor } \\
\text { relations in the company. } \\
\text { Employee and employer survey. } \\
\text { Simulation modelling of the influence of } \\
\text { the main elements of social and labor } \\
\text { relations on the purposeful activities, } \\
\text { motivation, labour productivity and } \\
\text { personal involvement. }\end{array}$ & $\begin{array}{l}\text { Personnel certification. Assessment } \\
\text { of correlation between subsystems of } \\
\text { selection, recruitment, training, and } \\
\text { development and labour } \\
\text { requirements. } \\
\text { Benchmarking. } \\
\text { Simulation meetings on changes in } \\
\text { the subsystems of planning, } \\
\text { selection, recruitment, and } \\
\text { development to develop functions, } \\
\text { methods, and tools. }\end{array}$ & $\begin{array}{l}\text { Analysis of management records regulating } \\
\text { HR functions: planning, organization, } \\
\text { stimulation, motivation and labour control. } \\
\text { Benchmarking. } \\
\text { Monitoring the implementation of HR } \\
\text { functions. } \\
\text { Function and cost-based analysis of } \\
\text { options relaed to the impact of changes in } \\
\text { tHR functions on labour productivity } \\
\text { and implementing enterprise's } \\
\text { development plans. }\end{array}$ \\
\hline 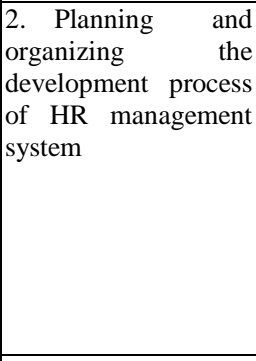 & $\begin{array}{l}\text { Coordination of plans: goals, tasks, } \\
\text { algorithms, resources needed to change } \\
\text { HR management system. } \\
\text { Simulation, network planning of changes } \\
\text { in the organizational structure of } \\
\text { management, goals, tasks, and HR } \\
\text { functions. } \\
\text { Project change management. }\end{array}$ & 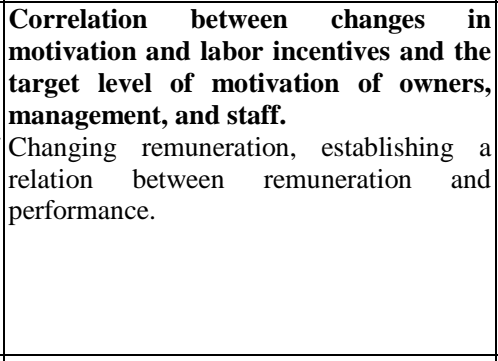 & $\begin{array}{l}\text { Planning and amending corporate culture. } \\
\text { Changing the system of evaluating and } \\
\text { coordinating the social and economic } \\
\text { benefits. } \\
\text { Planning and organizing interaction in the } \\
\text { labor process. } \\
\text { Changes in the personal interaction } \\
\text { between manager and employees, between } \\
\text { employees. } \\
\text { Promoting company's values among } \\
\text { employees. }\end{array}$ & $\begin{array}{l}\text { Network planning of changes in the } \\
\text { selection, recruitment, training, and } \\
\text { development. } \\
\text { Restructuring functions, methods of } \\
\text { marketing } \quad \text { subsystems, selection, } \\
\text { recruitment, placement, adaptation, } \\
\text { training, certification, career } \\
\text { opprtunities. }\end{array}$ & $\begin{array}{l}\text { Simulation, network planning, changes in } \\
\text { the organizational structure of management, } \\
\text { planning, organization, labor control,human } \\
\text { resources normation system. }\end{array}$ \\
\hline $\begin{array}{|lr|}\text { 3. } & \text { Institutionalizing } \\
\text { HR } & \text { development } \\
\text { tools } & \end{array}$ & $\begin{array}{l}\text { Developing and implementing a strategic } \\
\text { improvement plan. } \\
\text { Developing and implementing regulations } \\
\text { on the organizational structure of } \\
\text { management, functions, criteria and } \\
\text { indicators for evaluating HR performance. }\end{array}$ & \begin{tabular}{|l|} 
Developing, informing, and coordinating \\
regulations on remuneration. Developing, \\
changing employe share in performance- \\
based incentives. Employment agreement.
\end{tabular} & $\begin{array}{l}\text { Promoting ethical, aesthetic and moral } \\
\text { values in corporate culture, rules of } \\
\text { personal, and creating a favourable socio- } \\
\text { psychological climate. } \\
\text { Development and approval of regulations } \\
\text { for staff interaction in team work. }\end{array}$ & $\begin{array}{l}\text { Developing and implementing HR } \\
\text { policy: policy of planning, selection, } \\
\text { recruitment, placement, dismissal, } \\
\text { adaptation, training, professional and } \\
\text { social development. }\end{array}$ & $\begin{array}{l}\text { Developing and implemeting regulations } \\
\text { for organizational structure of } \\
\text { management, functions: planning, } \\
\text { organization, coordination, motivation and } \\
\text { control. }\end{array}$ \\
\hline 4. $\quad$ Outcome control & $\begin{array}{l}\text { Monitoring and control of indicators of } \\
\text { purposeful activities, labour productivity } \\
\text { and the implementation of business } \\
\text { development plans. }\end{array}$ & $\begin{array}{l}\text { Monitoring and controlling the level of } \\
\text { staff motivation to perform labor functions } \\
\text { and personal involvement in implementing } \\
\text { development plans. }\end{array}$ & $\begin{array}{l}\text { Monitoring and changing elements of } \\
\text { social and labor relations. }\end{array}$ & $\begin{array}{l}\text { Monitoring and control of quantity } \\
\text { and quality of human resources, } \\
\text { company's HR policy. }\end{array}$ & $\begin{array}{l}\text { Monitoring and quality control of } \\
\text { implemeting HR functions. }\end{array}$ \\
\hline
\end{tabular}

